\title{
Siting Commercial Fusion Power Plants
}

by

J. R. Young

September 1976

Prepared for the Energy Research and Development Administration under Contract E(45-1)-1830 
NOTICE

This report was prepared as an account of work sponsored by the United States Government. Neither the United States nor the Energy Research and Development Administration, nor any of their employees, nor any of their contractors, subcontractors, or their employees, makes any warranty, express or implied, or assumes any legal liability or responsibility for the accuracy, completeness or usefulness of any imformation, apparatus, product or process disclosed, or represents that its use would not infringe privately owned rights.

PACIFIC NORTHWEST LABORATORY

operated by

BATTELLE

for the

ENERGY RESEARCH AND DEVELOPMENT ADMINISTRATION

Under Contract E(45-1)-1830

Printed in the United States of America Available from

National Technical Information Service

U.S. Department of Commerce

5285 Port Royal Road

Springfield, Virginia 22151

Price: Printed Copy \$4.50; Microfiche \$2.25 


\section{6}

SITING COMMERCIAL FUSION POWER PLANTS

by

J. R. Young

September 1976

Battelle

Pacific Nortnwest Laboratories

Richland, Washington 99352 


\section{PREFACE}

Fusion reactor technology has developed far enough to expect laboratory demonstration of practical levels of fusion employing the D-T reaction to occur in the early 1980s. Following that demonstration, and depending upon the national priorities for energy from D-T fusion, construction and operation of experimental reactors and demonstration power reactors could occur before the end of this century. Operation of the first commercial power plants could then follow, starting about 2010 .

Development and adoption of a new power system eventually will require a description of the environmental effects in an environmental statement providing a comparison to the effects of competitive systems. In anticipation of that statement, an environmental analysis (BNWL-2010) has been prepared for the ERDA Division of Magnetic Fusion Energy. That analysis estimates the environmental effects of constructing and operating $D-T$ fusion reactors as an economically competitive source of electricity in the 21 st century.

The analysis has four primary purposes:

1. To describe the general nature of the environmental effects,

2. To determine current ability to estimate the effects,

3. To determine methods for reducing the effects, and

4. To determine research necessary for increasing capability to define and reduce the effects.

Timely identification of needed research and methods for reducing effects will permit the performance of that research and the revision of conceptual fusion power plant designs before preparation of the program environmental statement. This would improve the quality of the environmental statements and could reduce the estimated adverse environmental effects due to fusion power plants.

The environmental analysis (BNWL-2010) concludes that the following assumed characteristics are the best set for the first operating fusion power plants:

- The D-T fusion reaction

- Large quantities of activation products

- Kilogram quantities of tritium in the plant systems

- Massive reactor structures

- Large lithium inventories

- Large inventories of liquid metals and salts
- Standard electricity generation

- Standard radioactive waste systems

- Large magnetic fields

- A self-contained fuel cycle

- Rural siting

Using these characteristics a reference reactor was analyzed to determine the environmental effects by using available concepts of plant subsystems designs that control interactions with the environment or by assumption that best current technology would be used in subsystems design. Because this analysis does not take into account advances in both fusion and waste control technology during the next thirty years, the estimated effects probably are significantly higher than the actual effects will be for the first fusion power plants. The estimated environmental effects should be interpreted only as being the probable upper limit for the actual effects. 
Preparation of the fusion power plant environmental analysis required development and use of specially developed data and analysis methods not used in the preparation of current environmental statements for fossil and fission power plants. These data and analysis requirements are documented in a series of reference topical reports to make this information publicly available and to assure understanding of the basis for the conclusions made in the environmental analysis. These reference topical reports summarize the state-of-the-art as applicable to preparation of environmental statements for fusion power plants. They present the data and analytical techniques used in the environmental analysis to estimate the interactions with the environment and the resultant environmental effects. This information then was analyzed for adequacy and the need was determined for additional research to assure satisfactory ability to prepare environmental statements for the fusion development program and experimental facilities in the early 1980s. Estimated environmental effects are presented in these reference documents only as necessary to illustrate use of the data and analytical techniques.

This report is one of those reference documents for the environmental analysis. The other documents in this series contain more details of the power plant concepts and the probable environmental effects of fusion power plants with the assumed characteristics listed above. These documents are available through the National Technical Information Service:

An Environmental Analysis of Fusion Power to Determine Related R\&D Needs, BNWL-2010

Review of Fusion Research Program: Historical Summary and Program Projections, BNWL-2011

Fuel Procurement for First Generation Fusion Power Plants, BNWL-2012

Current Fusion Power PIant Design Concepts, BNWL-2013

Reference Commerical Fusion Power Plants, BNWL-2014

Siting Commercial Fusion Power Plants, BNWL-2015

Materials Availability for Fusion Power Plant Construction, BNWL-2016

Projected Thermodynamic Efficiencies of Fusion Power Plants, BNWL-2017

Tritium Source Terms for Fusion Power Plants, BNWL-2018

Management of Nontritium Radioactive Wastes from Fusion Power Plants, BNWL-2019

Methodology for Estimating Radiation Doses Due to Tritium and Radiocarbon Releases, BNWL-2020

Magnetic Field Considerations in Fusion Power Plant Environs, BNWL-2021

Biological Effects of Tritium Releases from Fusion Power Plants, BNWL-2022

Biological Effects of Activation Products and Other Chemicals Released from Fusion Power Plants, BNWL-2023

Safety Review of Conceptual Fusion Power Plants, BNWL-2024

An Investigation of the Transportation Requirements of Fusion Power Plants, BNWL-2025

Considerations of the Social Impact of Fusion Power, BNHL-2026

Environmental Impacts of Nonfusion Power Systems, BNWL-2027

Environmental Cost/Benefit Analys is for Fusion Power Plants, BNWL-2028

Biomagnetic Effects: A Consideration in Fusion Reactor Deveiopment, BNWL-1973

An Analysis of Tritium Releases to the Atmosphere by a CTR, BNWL-1938 


\section{CONTENTS}

INTRODUCTION

SUMMARY AND CONCLUSIONS

BACKGROUND

GENERAL POWER PLANT SITING REQUIREMENTS

PROXIMITY TO LOAD CENTERS

AVAILABILITY OF WATER

LAND REQUIREMENTS

GEOLOGY AND SEISMOLOGY

METEOROLOGY

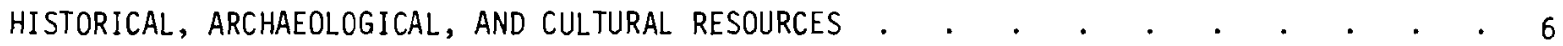

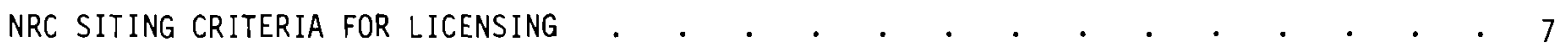

OTHER REGULATORY REQUIREMENTS . . . . . . . . . . . . . . . . . . . . . 9

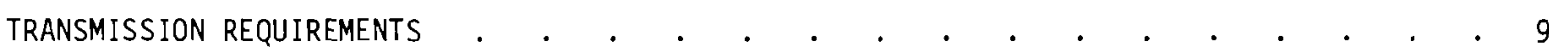

SITING FUSION POWER PLANTS . . . . . . . . . . . . . . . . . . . . . 10

THE FIRST COMMERCIAL POWER PLANTS $•$ •

THE ADVANCED POWER PLANTS . . . . . . . . . . . . . . . . . . . . . . . . . 11

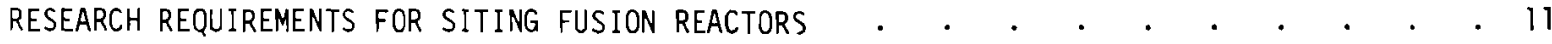

REFERENCES . . . . . . . . . . . . . . . . . . . . . . . . . . 12

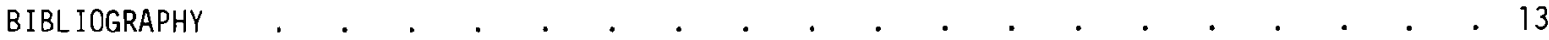


SITING COMMERCIAL FUSION POWER PLANTS

INTRODUCTION

The characteristics of the site selected for a power plant have a significant effect on the environmental impacts of $i$ ts construction and operation and on the economic cost of the electricity produced. Siting the piant close to a major electricity load center such as a large city is usually desirable to reduce the cost for transmitting the electricity, increase the reliability of the electricity supply, and reduce the adverse socioeconomic effects due to the construction force. However, it may be desirable to locate the plant as far as possible from population centers to reduce the environmental effects. As a result, the best site often is selected by a balance between these opposing requirements.

Selection of the best site for a fusion reactor is expected to require the same siting considerations as does selection of a site for a current power plant. The final choice of site, however, may differ because of differences in the amounts and types of pollutants released.

This document discusses siting requirements for fusion power plants. The current concept of the reference first commercial reactors was developed from analys is of the characteristics of current design concepts. Because those reactors use the deuterium-tritium fuel reaction, large quantities of activation products and tritium are created and must be considered as potential sources of radiation doses (Young, 1976 and Young and Gore, 1976). However, advanced reactors using fuel reactions that neither consume nor create radionuclides are briefly considered.

\section{SUMMARY AND CONCLUSIONS}

The primary siting requirements for a large power plant are:

1. Proximity to load centers,

2. Availability of cooling water,

3. Ample land area,

4. Satisfactory geology and seismology,

5. Minimum impact on historical and archaeological sites,

6. Minimum adverse socioeconomic impact due to employment of both construction and operating personne], and

7. Minimum environmental impact due to releases of pollutants and presence of industrial facilities. 
Many fossil power plants are located within urban areas because methods are available to minimize the environmental impacts of pollutant releases. However, fission power plants usually are sited 10 to $50 \mathrm{miles}$ from urban centers because of concern about radiation doses from routine operation and accidental situations.

The first commercial fusion reactors probably will be sited closer to urban centers than current fission power plants. The presence of large quantities of activation products probably will require transport of solid radioactive waste to burial sites. The presence of large amounts of tritium probably will result in routine releases of very small quantities to the air and nearby water bodies. The probability of accidental releases of significant quantities of tritium or other radionuclides is expected to be very low because adequate engineering technology appears available to prevent such releases. Until technology indicates an even lower probability, it appears prudent to not site the first commercial reactors in urban centers. However, siting within 10 miles of urban centers probably will be possible without a significant probability of measurable radiation doses to the general public.

Advanced fusion reactor siting does not appear limited by concern about radionuclide releases. However, the large magnetic fields used within the reactors may make urban siting impractical because of interference with electronic and communications systems. Consequently, the conclusion at the present time is that (1) siting advanced reactors close to urban centers appears quite possible and that (2) siting advanced reactors in urban areas may be possible if designs that do not use magnetic fields are feasible.

Ample technology currently is available for describing the siting requirements for fusion power plants. Siting industrial facilities has been studied sufficientiy for fossil and fission powe plants to provide the needed technology.

Study of siting the first commercial fusion power plants indicates that the primary impact of siting is use of large land areas due to the presence of radionuclides and magnetic fields.

The only apparent methods for reducing these large land requirements are to use advanced fusion reactors which do not create radionuclides and to use inertial confinement, which does not need magnetic fields.

\section{Research Requirements}

Research is needed to establish siting criteria for power plants and experimental facilities. Nuclear power plant siting has been studied extensively with siting criteria stated in NRC Regulatory Guide 4.7. The requirements for nuclear power plants should be studied and modified as appropriate for fusion facilities. No other research related to siting of fusion power plants and experimental facilities appears necessary to assure adequate ability to write environmental sta tements. 
BACKGROUND

A site is the real estate that is owned, leased, or otherwise controlled by a utility for construction and operation of a power plant. The terms fusion power plant or nuclear power central station refer to a power generation complex containing one or more reactors and the turbine generating units plus auxiliary facilities, equipment, and structures necessary to maintain and operate the reactors.

The siting of fusion power plants is expected to be guided by the practices, guidelines, and criteria that are being developed and established through experience gained in the construction and operation of several generations of large fossil and nuclear power plants. Although major changes in the current guidelines are not expected, refinements in application probably will occur.

Power plant siting must be responsive to the public's concern for the quality of the environment. Factors to be considered include: proximity of load centers; availability of access and transportation; adequacy of geological conditions for engineering and safety requirements; suitability of meteorological and hydrological conditions, and anticipated environmental impacts caused by the construction and operation of the plant.

Responsibility for investigating, selecting and procuring a specific site for a nuclear power plant normally rests with the utility. However, authority for approving construction and operation of the plant at the site rests with the NRC and other governmental bodies, both state and federal. Such authority is exercised through the issuance of permits and licenses following routine and extensive considerations and hearings by officials, boards, and commissions. Economic, safety, and environmental requirements are considered before licensing new or previously approved sites.

Studies have been made on the generalized problem of power plant siting. A cooperative study by federal and state groups (Energy Policy, 1969), recommends that plans for power plant siting consider the following:

Compliance with safety criteria for nuclear plants as prescribed by the AEC;* Compliance with air pollution criteria and standards as established by the states and the National Air Pollution Control Administration of HEW; *

Compliance with the water quality standards for thermal effects as established by the states and the Federal Water Pollution Control Administration (FWPCA) of the U.S. Department of the Interior; **

\footnotetext{
*The Atomic Energy Commission's regulatory functions were transferred to the Nuclear Regulatory Commission in January 1975.

**The Department of the Interior and Department of Health, Education, and Welfare functions indicated were transferred to the Environmental Protection Agency by Reorganization Plan No. 3 of 1970.
} 
Development of opportunities for public recreation at plant sites;

Consideration of aesthetic values and attention to the appearance of power plant facilities and associated transmission lines;

Recognition of rural development considerations in plant siting;

Siting and lead-time requirements for reliability of service;

Impact on defense preparedness of particular sites and power plant capacities;

The routing of associated transmission lines and the problems of rights-of-way at various alternative plant locations;

Assuring that the plant will be of sufficient size to meet regional loads including mutually agreeable arrangements for meeting the bulk power needs of the small utilities;

Prospects for combining power plants with other purposes such as desalting plants, industrial centers, and even new cities.

These are considerations over and above basic requirements of sufficient land, the availability of transmission lines, fuel, and other materials that every utility considers before deciding on the size, type, and location of a power plant. 


\section{GENERAL POWER PLANT SITING REQUIREMENTS}

Siting of power plants generally requires a balancing of two opposing requirements: low electricity costs and low adverse environmental effects. As a general rule, reducing the amount of adverse environmental impact results in increased economic costs. Selection of the best site often is difficult because universally-accepted economic values are not available for environmental impacts and because some impacts affect only a small fraction of the total population.

Each of the most important site requirements for power plants is discussed below. The less important requirements are not discussed primarily because (1) methods are available for preventing significant adverse effects or (2) the effects are too small to influence the decision of a specific site selection. A bibliography is included in this document for those wishing detailed information on power plant siting.

Many mandatory requirements must be satisfied by any site considered in the final comparison to select the best power plant site. In our analysis of fusion reactor siting, such requirements were assumed satisfied by numerous sites available in all regions of the country. Examples of requirements easily met are satisfactory foundation conditions, availability of transportation for fuels and structural materials, availability of construction and operating personnel, and no probability of serious natural events such as floods.

\section{PROXIMITY TO LOAD CENTERS}

Short electricity transmission distances are desirable for three reasons:

- The electricity transmission cost is essentially proportional to the transmission distance,

- The environmental impact of transmission lines is proportional to the length of the lines, and

- The probability of interruption of a transmission system operation is essentially proportional to the length of the lines.

The ideal transmission situation is to site power plants at the load center, e.g., in a large city or industrial complex. This results in minimum transmission cost and maximum transmission reliability.

\section{AVAILABILITY OF WATER}

Water is needed for dissipation of waste heat rejected by power plants. Dry cooling has not been developed for large power plants and may result in higher electricity costs than wet cooling because of the expected lower efficiency for converting heat energy to electricity. 
The amount of water needed for cooling power plants depends on the type of cooling. Oncethrough cooling requires about $1500 \mathrm{cfs}$ for a 1200 MWe plant. Closed cycle cooling with towers, ponds or canals requires much less water: about $100 \mathrm{cfs}$ for a 1200 MWe plant.

In once-through cooling the pumping of large volumes of water can have a significant mechanical effect on aquatic life. Heating that water and the nearby water body into which it is released can have a significant thermal effect on aquatic life. Closed-cycle systems have lower mechanical and thermal effects but may have effects due to localized release of corrosion-inhibitors and biocides to nearby water bodies plus heat and moisture to the atmosphere. In some locations fog created by cooling towers has an aesthetic impact and may create a safety hazard for nearby residents.

\section{LAND REQUIREMENTS}

Present nuclear power plants of 1200 MWe capacity require 100 to 400 acres of land to meet construction and operational requirements which includes cooling towers, switch yards, parking areas, roads, railroad spurs, and related facilities. Area requirements for a fusion plant are expected to be much the same, particularly if there are radionuclides or large magnetic fields in the plant. Multiple units of the same capacity could be acconmodated by additional areas of tens of acres per additional unit. If a cooling pond is used for dissipation of waste heat, an additional 1000 to 2000 acres would be required for each reactor plant unit, depending on the site location and the meteorological conditions (Edinger and Geyer, 1965).

\section{GEOLOGY AND SEISMOLOGY}

Safety and engineering requirements dictate the consideration of geological factors in the selection of specific sites to assure a satisfactory foundation for the plant structures. The presence of faulting should be considered. A site should have no known faults and be sufficiently removed from capable faults to preclude damage to systems containing radionuclides in the event of an earthquake.

\section{METEOROLOGY}

Meteorological parameters at a prospective site must be identified on a seasonal and annual basis from data recorded on or near the site. Knowledge of these conditions is necessary to assess the environmental impacts of cooling ponds, cooling towers, and spray canals and is important in determining the behavior of radioactive materials which might be released during plant operation. The preferred meteorology results in rapid dilution and travel of pollutants away from population centers.

\section{HISTORICAL, ARCHAEOLOGICAL, AND CULTURAL RESOURCES}

Areas valued for historical, scenic, cultural, or natural significance should be avoided when selecting a plant site. The 1966 National Historic Preservation Act protects historic sites in the U.S. and funds state and local groups to study and identify such sites. The National 
Register of Historic Places (1969) identified these sites. Sites are listed periodically in the Federal Register and is updated by monthly notices. National landmarks were identified in the Federal Register of January 29, 1972.

\section{NRC SITING CRITERIA FOR LICENSING}

Nuclear power plants must be 1 icensed by the NRC before they can be constructed or operated. Requirements for licensing are for the purpose of protecting the general public and the environment. Part 100 (Reactor Site Criteria) of Title 10, Code of Federal Regulations and subsequent revisions and amendments is used to evaluate the acceptability of proposed reactor sites. An applicant for a construction permit is required to identify the following:

(a) "Exclusion area" which is that area surrounding the reactor, in which the reactor licensee has the authority to determine all activities including exclusion or removal of personnel and property from the area. This area may be traversed by a highway, rail road, or waterway, provided these are not so close to the facility as to interfere with normal operations of the facility and provided appropriate and effective arrangements are made to control traffic on the highway, railroad, or water, in case of emergency, to protect the public health and safety. Residence within the exclusion area shall normally be prohibited. In any event, residents shall be subject to ready removal in case of necessity. Activities unrelated to operation of the reactor may be permitted in an exclusion area under appropriate limitations, provided that no significant hazards to the public health and safety will result.

(b) "Low population zone" which is the area imediately surrounding the exclusion area which contains residents, the total number and density of which are such that there is a reasonable probability that appropriate protective measures could be taken in their behalf in the event of a serious accident. These guides do not specify a permissibie population density or total population within this zone because the situation may vary from case to case. Whether a specific number of people can, for example, be evacuated from a specific area or instructed to take shelter, on a timely basis will depend on many factors such as location, number and size of highways, scope and element of advance planning, and actual distribution of residents within the area.

(c) "Population center distance" which is the distance from the reactor to the nearest boundary of a densely populated center containing more than 25,000 residents.

The NRC lists other considerations in 10 CFR 100:

Factors considered in the evaluation of sites include those relating both to the proposed reactor design and the characteristics peculiar to the site. Plans for reactor design, construction and operation are expected to reflect an extremely low probability for 
accidents that could result in release of significant quantities of radioactive fission products. The site location and the engineered features included as safeguards against the hazardous consequences of an accident, should one occur, are expected to insure a low risk of public exposure. In particular, the Commission will take the following factors into consideration in determining the acceptability of a site for a power or testing reactor:

(a) Characteristics of reactor design and proposed operation including:

(1) Intended use of the reactor including the proposed maximum power level and the nature and inventory of contained radioactive materials;

(2) the extent to which generally accepted engineering standards are applied to the design of the reactor;

(3) the extent to which the reactor incorporated unique or unusual features having a significant bearing on the probability or consequences of accidental release of radioactive materials;

(4) the safety features that are to be engineered into the facility and those barriers that must be breached as a result of an accident before a release of radioactive material to the environment can occur.

(b) Population density and use characteristics of the site environs, including the exclusion area, low population zone, and population center distance.

(c) Physical characteristics, including seismology, meteorology, geology, and hydrology.

(1) Appendix A, "Seismic and Geologic Siting Criteria for Nuclear Power Plants," describes the nature of investigations required to obtain the geologic and seismic data necessary to determine site suitability and to provide reasonable assurance that a nuclear power plant can be constructed and operated at a proposed site without undue risk to the health and safety of the public. It describes procedures for determining the quantitative vibratory ground motion design basis at a site due to earthquakes and describes information needed to determine whether and to what extent a nuclear power plant need be designed to withstand the effects of surface faulting.

(2) Meteorological conditions at the site and in the surrounding area should be considered.

(3) Geological and hydrological characteristics of the proposed site may have a bearing on the consequences of an escape of radioactive material from the facility. Special precautions should be planned if a reactor is to be located at a site where a significant quantity of radioactive effluent might accidently flow into nearby streams or rivers or might find ready access to underground water tables. 
(d) Where unfavorable physical characteristics of the site exist, the proposed site may nevertheless be found to be acceptable if the design of the facility includes appropriate and adequate compensating engineering safeguards.

OTHER REGULATORY REQU IREMENTS

Federal, state, and local standards must be considered in the evaluation of prospective sites. The U.S. Environmental Protection Agency (EPA) is responsible for controlling air and water pollution, drinking water quality, solid wastes, environmental radiation and noise (NEPA, 1970). Other agencies responsible for standards are: the Federal Power Commission (16USC); U.S. Department of the Army (33USC, 1970); the U.S. Department of the Interior (Energy Policy, 1969); and the U.S. Department of Commerce, National Oceanic and Atmospheric Administration. State agencies also set regulations to control air and water quality as well as zoning, public services, pollution, wildlife and recreation (Energy Policy, 1969).

The Federal Water Pollution Control Act Amendments of 1972 provide for the states to reduce water pollution within the framework of a national program. The utilities are required to adhere to FWPCA criteria and to requirements of discharge permits issued by state or federal agencies.

\section{TRANSMISSION REQUIREMENTS}

Rights-of-way required for the transmission lines must be taken into consideration when selecting a power plant site. Economic and environmental impact comparisons should be made of the alternative routing available at each site being considered. Impacts due to the transmission lines can vary depending upon the sites and routes.

Present power plants of advanced design use transmission lines designed for $765 \mathrm{kV}$ operation which require a right-of-way 280 feet in width. A 3000 MWe station would require two adjacent lines with a right-of-way 430 feet in width (Energy Policy, 1969).

Selection of routings for transmission lines would consider many of the same factors as for plant siting. Safety requirements are different so NRC regulatory criteria do not apply. However, environmental effects are reviewed by the NRC in its assessment of impacts (USNRC Regulatory Guide 4.2). The review includes impacts on the soils caused by construction and maintenance of transmission lines; effects on river and stream banks at line crossings; impacts on terrestrial and aquatic ecosystems during construction; economic impacts resulting from the purchase of right-of-way land and possible changes in land use; electrical radiation effects including electromagnetic interference with communication systems, induced voltages in paralleling systems, audible noise emission, and ozone concentration; and visual aesthetic values. 


\section{SITING FUSION POWER PLANTS}

Two general types of fusion power plants are expected to be built: (1) the first commercial plants that consume or create radionuclides and (2) the advanced power plants that neither consume nor create radionuclides.

\section{THE FIRST COMMERCIAL POWER PLANTS}

The first commercial power plants are expected to use fusion reactions that have the least severe operating conditions. As a result the reference reactor for the first power plants is expected to have the following characteristics (Young, 1976, BNWL-2014):

The $D-T$ fusion reaction

Large quantities of activation products

kilogram quantities of tritium in the plant system

Massive reactor structures

Large lithium inventories

Large inventories of liquid metals and salts

Standard electricity generation systems

Standard radioactive waste systems

Large magnetic fields

A self-contained fuel cycle

The environmental analysis (Young, 1976, BNWL-2010) shows that this reactor might have the following environmental interactions that would significantly influence the site selection:

1. Release of very small quantities of tritium,

2. Transportation of solid radioactive waste to burial sites,

3. A very low potential for accidental releases of liquid metal coolants and radionuclides,

4. Large plant areas to preclude effects on the public of magnetic fields,

5. Large heat releases, and

6. The aesthetic impact of large structures and cooling towers.

Because of the presence of radionuclides and small releases that may occur, siting the first generating plants in urban areas does not appear practical. However, siting more than 10 miles from urban areas probably will not be necessary. The accident analyses indicate that proper design will probably reduce the accidental releases of significant amounts of radionuclides to zero. The radionuclides that could be released appear to be of less biological concern than the plutonium and fission products in fission power plants. Transportation of solid waste through unpopulated areas would be desirable to reduce the probability of accidental radiation doses.

The large magnetic fields required in some fusion reactor concepts would make siting in urban areas undesirable because of the interference with electronic and communications systems. Large exclusion areas would be needed to prevent such interference and such land use in urban areas seems to be impractical. 
Conclusion

As a result of the above considerations, the first commercial fusion power plants probably will be sited from 5 to $10 \mathrm{miles}$ from urban areas to preclude significant radiation doses from waste shipments and routine operational releases. Although significant accidental releases probably would be rare, this distance to the nearest urban center probably would be ample for enough dilution of releases to prevent significant effects.

THE ADVANCED POWER PLANTS

Some time after introduction of the first commercial fusion power plants, technology may have advanced far enough that fusion reactors neither consuming nor creating radionuclides can be used. In that case the power plant is visualized as having these characteristics:

- A reaction chamber surrounded by a shield to contain alpha, beta, and gamma radiation

- A fuel supply system

- A magnetic or laser system for creating fusion conditions

- An electricity generation system which will include a standard turbine-generator system and possibly a direct conversion system

- A waste heat dissipation system

- Nonradioactive waste disposal systems

The only characteristics of these reactors that might preclude siting in ar urban area are the possible presence of large magnetic fields and the disposal of waste heat. If inertial confinement fusion is used, magnetic fields may not be needed. Waste heat may become an economic asset if it can be used for space heating in the winter and for operation of air-conditioning systems in the summer.

Conclusion

The advanced fusion reactors probably can be sited close enough to urban regions to permit most of the advantages of short transmission systems and a large supply of construction labor. However, siting on the edge of urban areas may be necessary if large magnetic fields are used or large quantities of waste heat are dispersed to the atmosphere.

\section{RESEARCH REQUIREMENTS FOR SITING FUSION REACTORS}

Ample experience and knowledge are available for determining the best siting conditions for power plants. The recent regulatory requirements for nuclear power stations have resulted in extensive investigations of siting requirements and issue of regulatory guides on the general site suitability criteria for nuclear power stations (Regulatory Guide 4.7, U.S. Nuclear Regulatory Commission). 
Because fission power plants have a higher potential for radiation doses to the general public than fusion plants have, Regulatory Guide 4.7 may be more restrictive than is necessary. for fusion power plants and experimental facilities. In particular, the current requirement that the population density within 30 miles not exceed 500 persons per square mi 1 e $(1,415,000$ persons total) may be too restrictive because of a lower probability of significant release of radionuclides at fusion power plants and experimental facilities. As a result, the requirements of that regulatory guide should be reviewed and modified as appropriate for the expected characteristics of fusion facilities.

No other research related to siting of fusion power plants and experimental facilities has been identified as necessary to assure satisfactory preparation of the environmental statements expected to be issued in the early 1980s.

\section{REFERENCES}

Code of Federal Regulations, Part 100 of Title 10, Reactor Site Criteria.

Current List of Historic Places, Federal Register, Feb 10, 1976.

Edinger, J. E., and J. C. Geyer, Heat Exchange in the Environment, EEI Publication No. 65-902, Edison Electric Institute, June 1965.

Energy Policy Staff, Office of Sciences and Technology, Considerations Affecting Steam Power Plant Site Selection, 1969.

National Landmarks, Federal Register, Jan 29, 1972.

National Register of Historic Places, 1969.

NEPA, National Environmental Policy Act of 1969, 42USC, Paragraphs 4321-4347, 1970.

USNRC Regulatory Guide 4.2, Preparation of Environmental Reports for Nuclear Power Plants, Directorate of Regulatory Standards, U.S. Nuclear Regulatory Commission.

USNRC Regulatory Guide 4.7, Siting Criteria for Nuclear Power Plants, Directorate of Regulatory Standards, U.S. Nuclear Regulatory Commission, Washington, D.C.

Young, J. R., Environmental Effects of Fusion Power Plants, BNWL-2010, Battelle, Pacific Northwest Laboratories, Richland, WA, 1976.

Young, J. R. and B. F. Gore, Reference Commercial Fusion Power Plants, BNWL-2014, Batte11e, Pacific Northwest Laboratories, Richland, WA, 1976.

16USC, Paragraphs 791-828c, The Federal Power Act.

33USC, Paragraph 401-466, Rivers and Harbor Act of 1899, Corps of Engineers, U.S. Department of the Army, 1970. 


\section{BIBLIOGRAPHY}

Considerations Affecting Steam Power Plant Site Selection, The Energy Policy Staff, Office of Science and Technology, Dec 1968.

Siting Thermal Power Plants in California, State of California, House Resolution 459, Feb 1970.

F. J. Kempf and J. F. Fletcher, Effects of Site Location on the Capital Costs of Nuclear Electric Plants, BNWL-960, Battelle, Pacific Northwest Laboratory, Richland, WA, Mar 1969.

J. D. Calvert, W. L. Heilman and H. L. Smith, Nuclear Power Plant Siting, A Generalized Process, Commonwealth Associates, Inc., Aug 1974.

W. Ramsey and P. R. Reed, Land Use and Nuclear Power Plants, WASH-1319, Directorate of Regulatory Standards, USAEC.

D. B. Emerson, H. T. Hopkins, G. R. Squire and G. M. Sitek, General Environmental Guidel ines for Evaluating and Reporting the Effects of Nuclear Power Site Preparation, Plant and Transmission Facilities Construction, Hittman Associates, Inc., Feb 1974.

E. Graf-Webster, S. Haus, S. Lubore, J. Pfeffer and J. Watson, Legislation and Regulation of Utility Corridors and Power Plant Siting, M75-18, The Mitre Corp., Washington, DC, Feb 1975.

F. H. Warren, Nuclear Power Plant Siting, AF Program Report, Vol 1, No. 6, Atomic Industrial Forum, Inc., 0ct 1973.

E. Graf-Webster, S. Haus, S. Lubore, J. Pfeffer, and J. Watson, Methodologies for Power Plant Siting, M75-19, The Mitre Corp., Washington, DC, Feb 1975. 
A. A. Churm ERDA Chicago Patent Group

9800 S. Cass Avenue

Argonne, IL 60439

J. W. Beal

ERDA Div. of Magnetic

Fusion Energy

Washington, DC 20545

S. 0. Dean

ERDA Div. of Magnetic

Fusion Energy

Washington, DC 20545

E. E. Kintner

ERDA Div. of Magnetic

Fusion Energy

Washington, DC 20545

J. M. Williams

ERDA Div. of Magnetic

Fusion Energy

Washington, DC 20545

J. N. Grace

ERDA Div. of Magnetic

Fusion Energy

Washington, DC 20545

J. Baublitz

ERDA Div. of Magnetic

Fusion Energy

Washington, DC 20545

3 F. E. Coffman

ERDA Div. of Magnetic

Fusion Energy

Washington, DC 20545

J. F. Decker

ERDA Div. of Magnetic

Fusion Energy

Washington, DC 20545

3 K. M. Zwilsky

ERDA Div. of Magnetic

Fusion Energy

Washington, DC 20545

Dr. Philip M. Stone

ERDA Applied Plasma Physics

Program

Washington, DC 20545

G. W. Kuswa

ERDA Div. of Laser Fusion

Washington, DC 20545
OFFSITE

R. Blaunstein

ERDA Div. of Biomedical

and Environmental Research

Washington, DC 20545

H. M. Busey

ERDA Div. of Military

Application

Washington, DC 20545

M. A. Bell

ERDA Div. of Safety

Standards and Compliance

Washington, DC 20545

27 ERDA Technical Information Center

M. S. Kaminsky

Argonne National Laboratory

9700 S. Cass Avenue

Argonne, IL 60439

V. A. Maroni

Argonne National Laboratory

9700 S. Cass Avenue

Argonne, IL 60439

P. M. Persiani

Argonne National Laboratory

9700 S. Cass Avenue

Argonne, IL 60439

M. Petrick

Engineering and Technology

Division

Argonne National Laboratory

9700 S. Cass Avenue

Argonne, IL 60439

W. E. Parkins, Manager

Atomics International

Component Engineering and

Technology Division

North American Rockwell

P. 0. Box 309

Canoga Park, CA 91304

D. Gurinsky

Brookhaven National Laboratory

ERDA Brookhaven Area Office

Upton, NY 11973

H. J. Kouts

Brookhaven National Laboratory ERDA Brookhaven Area Office

Upton, NY 11973

S. Pearlstein

Brookhaven National Laboratory

ERDA Brookhaven Area office

Upton, NY 11973
OFFSITE

J. R. Powell

Brookhaven National Laboratory

ERDA Brookhaven Area Office

Upton, NY 11973

A. J. Impink, Jr

Carnegie Melion University

Pittsburgh, PA 15213

R. A. Gross

Plasma Research Laboratory

236 SW Mudd Bldg.

Columbia University

New York, NY 10027

W. C. Gough

Electric Power Research Inst.

3412 Hillview Ave.

Palo Alto, CA 94304

G. R. Hopkins

Gulf General Atomic

P.0. Box 1111

San Diego, CA 92112

Zeinab Sabri

Iowa State University

261 Sweeney Hall

Nuclear Engineering Department

Ames, IA 50010

R. Borg

Lawrence Livermore Laboratory

P. 0 . Box 808

Livermore, CA 94550

T. K. Fowler

Lawrence Livermore Laboratory

P.O. Box 808

Livermore, CA 94550

R. Moir

Lawrence Livermore Laboratory

P.0. Box 808

Livermore, CA 94550

A. Carl Haussmann

Lawrence Livermore Laboratory

P.O. Box 808

Livermore, CA 94550

J. Hovingh

Lawrence Livermore Laboratory

P.0. Box 808

Livermore, CA 94550

R. F. Post

Lawrence Livermore Laboratory

P.0. Box 808

Livermore, CA 94550

C. J. Taylor

Lawrence Livermore Laboratory

P.0. Box 808

Livermore, CA 94550 
$R$. Werner

Lawrence Livermore

Laboratory

P.0. Box 808

Livermore, CA 94550

L. L. Wood

Lawrence Livermore

Laboratory

P.O. Box 808

Livermore, CA 94550

W. Bauer

Division Supervisor of Physical Research

Sandia Labs Livermore

Livermore, CA 94550

L. Booth

Los Alamos Scientific Laboratory

CTN Research

P.0. Box 1663

Los Alamos, NM 87544

D. J. Dudziak

Los Alamos Scientific

Laboratory

CTN Research

P.0. Box 1663

Los Alamos, NM 87544

D. B. Henderson

Los Alamos Scientific Laboratory

CTN Research

P.0. Box 1663

Los Alamos, NM 87544

E. L. Kemp

Los Alamos Scientific

Laboratory

CTN Research

P.0. Box 1663

Los Alamos, NM 87544

F. L. Ribe

Los Alamos Scientific

Laboratory

CTN Research

P.0. Box 1663

Los Alamos, NM 87544

L. Stewart

Los Alamos Scientific

Laboratory

CTN Research

P.0. Box 1663

Los Alamos, NM 87544

K. Thomassen

Los Alamos Scientific

Laboratory

CTN Research

P.0. Box 1663

Los Alamos, NM 87544 o. K. Harling

Massachusetts Institute of

Technology

Cambridge, MA 02139

Bruno Coppi

Department of Physics

Massachusetts Institute of

Technology

Cambridge, MA 02139

L. Lidsky

Dept. of Nuclear Engineering

Massachusetts Institute of

Technology

Cambridge, MA 02139

Norm Rasmussen

Dept. of Nuclear Engineering

Massachusetts Institute of

Technology

Cambridge, MA 02139

David Rose

Massachusetts Institute of

Technology

Cambridge, MA 02139

R. E. Stickney

Mechanical Engineering

Massachusetts Institute of

Technology

Cambridge, MA 02139

J. J. Reinmann

NASA - Lewis Research Center 2100 Bookpark Rd.

Cleveland, $\mathrm{OH} \quad 44135$

Vincent Arp

National Bureau of Standards

Cryogenics Division

Boulder, CO 80302

J. F. Clarke

Oak Ridge National

Laboratory

P.0. Box Y

Oak Ridge, TN 37830

A. P. Fraas

Oak Ridge National

Laboratory

P.0. Box Y

oak Ridge, TN 37830

J. Rand McNally, Jr. Oak Ridge National

Laboratory

P.O. Box Y

Oak Ridge, TN 37830

D. Steiner

Oak Ridge National

Laboratory

P. O. Box $Y$

oak Ridge, TN 37830

\section{OFFSITE}

J. $S \cot t$

Oak Ridge National Laboratory

P. 0. Box $X$

Dak Ridge, TN 37830

J. Banford

Physics International

2700 Merced St.

San Leandro, CA 94577

R. A. Huse

Public Service Electric

and Gas Co.

80 Park Place

Newark, NJ 07101

M. Gottlieb

Princeton University, PPPL

P.0. Box 451

Princeton, NJ 08540

R. G. Mills

Princeton University

P.0. Box 451

Princeton, NJ 08540

E. C. Tanner

Princeton University

P.0. Box 451

Princeton, NJ 08540

H. Perkins

Dept. of Chemistry

Princeton University

Princeton, NJ 06540

R. E. Gold

303 Sayre Hall

Forrestal Campus

P.0. Box 451

Princeton, NJ 06540

M. Kristiansen

Texas Tech. University

Lubbock, TX 79409

A. F. Haught

United Aircraft Research Lab.

United Aircraft Corporation

East Hartford, CT 06108

L. Levine

U.S. Naval Research Laboratory Washington, DC 20390

C. Z. Serpan, Ur.

U.S. Naval Research Laboratory

Washington, DC 20390

Francis Chen

University of California

Electronics Research

Laboratory

College of Engineering

Berkeley, CA 94720 
A. J. Lichtenberg University of California Electronics Research Laboratory College of Engineering Berkeley, CA 94720

Dave Okrent

U.C.L.A.

Los Angeles, CA 90024

C. D. Hendricks University of Illinois Nuclear Engineering Laboratory

Urbana, IL 61801

G. H. Miley University of Illinois Nuclear Engineering Laboratory Urbana, IL 61801

Terry Kammash University of Michigan Nuclear Engineering Department

Ann Arbor, MI 48105

Dean Abrahamson

University of Minnesota School of Public Affairs

Social Science

Building/309

Minneapolis, MN 55455

\section{W. G. Davey}

University of Texas Department of Physics Austin, TX 78712

E. Linn Draper, Jr. University of Texas Department of Physics Austin, TX 78712

W. E. Drummond University of Texas Department of Physics Austin, TX 78712

Abraham Hertzberg University of Washington Aerospace Research Laboratory 316 Guggenheim Seattle, WA 98105

A. L. Babb University of Washington Nuclear Engineering Department

Seattle, WA 98105
R. Conn University of Wisconsin Nuclear Engineering Department

Madison, WI 53706

G. L. Kulcinski University of Wisconsin Nuclear Eng ineering Department Madison, WI 53706

\section{W. Maynard} University of Wisconsin Nuclear Engineering Department Madison, WI 53706

D. Lichtman Department of Physics University of Wisconsin Milwaukee, WE 53201

E. E. Donaldson Washington State University Deparment of Physics Pullman, WA 99163

\section{D. Mahium}

Division of Biomedical

and Environmental Research

Washington, DC 20545

\section{J. V. Vanston}

Engineering Science

Building

University of Texas

Austin, TX 78712

Leslie S. Ramsey

450 North 5 th Street

Indiana, PA 15701 
ERDA Richland Operations Office

W. A. Burns

Atlantic Richfield Hanford Company

J. D. Kaser

Hanford Engineering Development Labs

D. G. Doran

H. H. Yoshikawa

\section{Battelle-Northwest}

D. T. Aase

G. S. Allison

T. W. Ambrose

D. G. Atteridge

D. A. Baker

J. L. Bates

M. A. Bayne

E. R. Bradley

J. L. Brimhall

R. L. Brodzinski

R. J. Brouns

L. R. Bunne11

L. L. Burger

S. H. Bush

N. E. Carter

T. D. Chikalla

R. G. Clark

T. L. Criswell

S. D. Dahlgren

M. T. Dana

D. E. Deonigi

R. L. Dillon

D. A. Dingee

P. J. Dionne

B. H. Duarle

J. W. Finnigan

J. C. Fox

J. J. Fuquay

J. E. Garnier

R. D. Gastil

B. F. Gore

J. N. Hartley

A. J. Haverfield

U. P. Jenquin

A. B. Johnson, Jr.

$R$. $H$. Jones

T. J. Kabele

W. S. Kelly

H. E. Kissinger

D. A. Kottwitz

N. Laegried

$B$. R. Leonard, ur

D. L. Lessor

H. B. Liemohn

R. C. Lijkala

M. A. Mckinnon

R. F. Maness

R. P. Marshall

\section{Battelle-Northwest - Continued}

E. S. Murphy

R. D. Helson

D. F. Newman

R. E. Nightingale

D. E. Olesen

L. T. Pedersen

R. T. Perry

D. R. Pratt

L. A. Rancitelli

J. F. Remark

U. S. Renné

R. E. Rhoads

W. D. Richmond

W. F. Sandusky

L. C. Schmid

N. M. Sherer

E. P. Simonen

R. I. Smith

J. K. Soldat

C. W. Stewart

K. B. Stewart

R. W. Stewart

J. A. Strand

D. L. Styris

A. M. Sutey

V. L. Teofilo

G. L. Tingey

M. T. Thomas

R. C. Thompson

L. H. Toburen

T. J. Trapp

R. Wang

R. E. Westerman

L. D. Williams

20 J. R. Young

M. G. Zimmerman

1 Technical Publications (BH)

5 Technical Information 